\title{
The role of spirituality as a coping mechanism for South African traffic officers
}

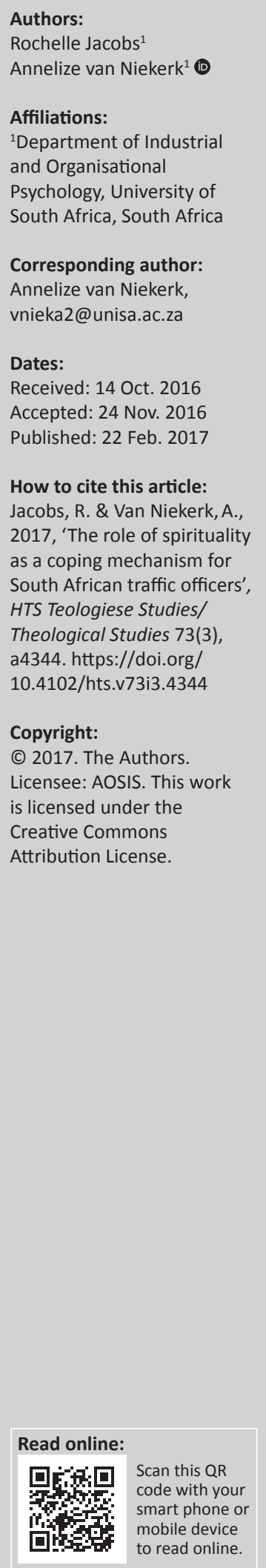

Traffic officers are faced with many stressful situations, yet each traffic officer might cope differently with these stressors. Spirituality is regarded as an essential defence in stressful situations. Therefore, this article provides a basic framework guiding traffic officers and practitioners, on how spirituality can be used as a coping mechanism when faced with various work-related stressors. An interpretative, qualitative study was conducted utilising purposive sampling in which 10 traffic officers participated in in-depth interviews. In line with the interpretive paradigm, data were analysed using content analysis. The research findings indicate when utilising spirituality to various degrees in their workplace, traffic officers displayed adaptive coping capabilities. Traffic officers associated less spirituality or a lack thereof with weaker coping capability. Furthermore, spirituality in traffic officers is informed by their spiritual or religious foundation, their purpose in work and life, their connection to a spiritual source, and the fruits of spirituality. The coping ability of traffic officers is influenced by their upbringing and background, by stressors in their work environment and by their coping mechanisms. The role of spirituality in the coping of traffic officers culminated in their ability to interpret the meaning of spirituality, and then implementing spirituality as a coping mechanism.

\section{Introduction}

The work of traffic officers is very important yet quite stressful, thus the need for emotional stability, self-awareness and stress management skills in their field (Pienaar 2007:3). Interestingly, people in general respond differently even when they are confronted with identical stressors (Louw \& Viviers 2010:1), and so do traffic officers. There might be various reasons for these different responses. One such reason might be situated in the concept of spirituality and how a person applies spirituality to cope more effectively in the place of work (Jacobs 2013:160; Moos 2002:67).

The context within which the South African traffic officer functions stems firstly from their appointment as prescribed by the National Road Traffic Act, No. 93 (1996). Accordingly, their duties include inspecting any vehicle for compliance within the provisions of this Act, temporarily forbidding a person from driving a vehicle should that person seem incapable, controlling and regulating traffic on any public road and requiring any person to furnish any particulars needed for identification. Actual law enforcement is done on all the public roads within the boundaries of a particular local municipal or provincial area (National Road Traffic Act 1996). The work environment of the traffic officer also includes the Law Enforcement Section within Traffic Services, where the officer carries out administrative duties. Secondly, traffic officers are appointed as peace officers in terms of section 334(1) (a) of the Criminal Procedure Act, No. 51 (1977), as published on 02 September 2011 (Gazette No. 34583, Regulation 707). These duties include all powers bestowed upon peace officers and all powers awarded to police officials, with the exclusion of specified sections and subject to certain provisions. Given the established overlapping nature of the duties of police officers and traffic officers, it is useful to consider findings from police research which are relevant to the current study.

Studies on policing and stress indicated that police work is indeed stressful (Anderson, Litzenberger \& Plecas 2002:399). Police tasks contain a spiritual element because in their job they pursue what is good, face threats to their lives and find their worth being ignored by the community (Smith \& Charles 2010:320). Similarly, the road environment places growing demands on traffic officers (Pienaar 2007:3), as they may be attacked by disgruntled motorists, targeted for their fire arms and thrown off motor cycles (Mushwana 1998:108). This may be detrimental to their well-being and affect the individual's perspective on life (Pienaar 2007:93; Smith \& Charles 2010:320). Nonetheless, research indicated that people can affect their own well-being through 
practices of forgiveness, spirituality and religion (Boehm \& Lyubomirsky 2009:8; Schreuder \& Coetzee 2011:275). The differences between, and the overlapping aspects related to, spirituality and religion are acknowledged (Collett 2011:50; Jacobs 2013:164; Karakas 2010:8; Kourie 2009:153; Welzen 2011:37) and often applied interchangeably and complimentary to each other (Kourie 2009:153).

\section{Spirituality}

Defining the complex concept of spirituality seems challenging (Jacobs 2013:1; Naidoo 2014:4) because of its subjective nature (Karakas 2010:26). Among the various definitions of spirituality, some or all of the following elements seem to be included: meaning and purpose, ethical values and beliefs, relationships or connectedness, and transcendence (Jacobs 2013:159). Other definitions describe a personal experience (Lombaard 2011:77; Waaijman 2007:5) searching for a persistent understanding of the existential self, connecting with the sacred (Karakas 2010:8), believing in a higher power and understanding life through lived experience (Jacobs 2013:160; Welzen 2011:38).

Spirituality relates to the place of work as 'spirit at work' and entails becoming aware of your higher self, within which one seeks to be purposeful in life and work (Kinjerski \& Skrypnek 2004:319; Schreuder \& Coetzee 2011:11). It is also concerned with cherished relationships with both a higher force and other people (Mohan \& Uys 2006:58). Connectedness with people is part of the need for self-actualisation in Maslow's hierarchy of needs, which motivates some people (Theron 2009:132). Motivation involves spiritual purpose which includes being driven by a need for spiritual wholeness, deeper meaning and the search for creative self-expression through work and relationships (Coetzee \& RoythorneJacobs 2007:162). 'Spirit at work' comprises interpersonal, physical, emotional, mental and spiritual characteristics, and this definite state entails physiological stimulation and positive affect (Kinjerski \& Skrypnek 2004:26). However, Naidoo (2014:3) cites Ali and Gibbs (1998) and shows that the work ethics of believers may also bring about disadvantages such as discrimination because of spiritual beliefs (Karakas 2010:26). Notwithstanding, adopting spirituality on a personal level also prompts people to consider ethical aspects, which leads to individual and societal transformation (Kourie 2009:168; Naidoo 2014:1). Hence, the benefits of spirituality in the workplace seem to outweigh the disadvantages (Van Tonder \& Ramdass 2009:2), with its motivating energy facilitating service regardless of challenges (Kinjerski \& Skrypnek 2004:28), which increases commitment and productivity (Naidoo 2014:1).

The post-modern approach recognises all these different views and truths on spirituality (Jacobs 2013:164) and emphasises the interconnectedness of living things (Kourie 2009:152). Even though literature indicates that there is no clear definition of spirituality (Jacobs 2013:1), it can be contested that the issue may be less about clarity, as commonalities in perspectives are evident (Mohan \& Uys
2006:58). Perhaps, the issue is more about whether there is a common definition understood by all, as there may be too many people defining spirituality differently. For the purpose of this study, spirituality is defined as individuals' experiences of the Divine (Lombaard 2011:77) on their journey of meaningful authentic self-discovery (Karakas 2010:8) and entails how people express these experiences through actions and attitudes (Lombaard 2011:77).

Existing research related to the spiritual experiences of traffic officers is either fairly old (Mushwana 1998; Van Heerden 1990) or explores spirituality from a police officer's perspective (Collett 2011; Joubert \& Grobler 2013; Karakas 2010; Kinjerski \& Skrypnek 2008; Pienaar \& Rothmann 2003). As 'spirit at work' begins with the individual and requires a holistic consideration of existence (Gnanaprakash 2013:383; Kourie 2009:151; Krok 2008:643), more attention needs to be given to the human element of traffic officers and not just to the law enforcement aspects of their profession (Pienaar 2007:5). Human elements include the values that drive them (Pienaar 2007:5) and how to cope with stress presented during the performance of their daily duties (Pienaar 2007:5). Research specific to the concept of coping of traffic officers seems to be limited (Pancheri et al. 2002; Pienaar 2007; Van Heerden 1990).

\section{Coping}

Generally, coping is a positive psychological construct (Coetzee \& Viviers 2007:485), which refers to the perceptual, mental or behavioural efforts that people employ to deal with situations deemed potentially difficult and stressful (Schreuder \& Coetzee 2011:383). Coping ability may be viewed by some as the presence or absence of coping skills (Ryan, Rapley \& Dziurawiec 2014:1069), but may differ in the extent to which contextual factors, such as social factors as opposed to individual factors, are considered (Ryan, Rapley \& Dziurawiec 2014:1069). For the purpose of this study, coping is viewed as the efforts employed by individuals to reduce the negative influences of stress on personal well-being, which may involve individual resources as well as their perceptions of challenges (Cheng, Mauno \& Lee 2014:73; Edwards 1988:243).

Lack of coping skills may negatively affect employees and organisations, through poor service to society, increased employee absenteeism and turnover (Dewe, O'Driscoll \& Cooper 2010). Pienaar (2007:93) propose the solution to be increased traffic officer training at departmental level focused at assisting them to cope better with stressors. Generally, internal organisational stressors include red tape, internal politics and role uncertainty (Luthans 2008:249). External organisational stressors include technology, changes in the economy, globalisation, the effects of family on the community, and race and gender considerations (Luthans 2011:282). Traffic officers might be faced with internal organisational stressors such as rotating work shifts, tight controls and demanding work conditions, as well as external organisational stressors such as those listed above. According 
to Pienaar, Rothmann and Van De Vijver (2007:14), people can manage the effects of negative work experiences by confronting the stressors and looking for lessons in such experiences from a religious perspective.

\section{Theoretical relationship}

The theoretical relationship between spirituality and coping in the workplace has been explored and is depicted in Figure 1. Trends in the literature indicate the influence of spirituality on coping (Gnanaprakash 2013:383; Krok 2008:643) and that people may respond differently given the same challenges (Louw \& Viviers 2010:1). The same stressor may be posed to different people. Yet, higher and lower levels of spirituality result in the application of positive and negative thoughts, respectively. Therefore, according to Rowe and Allen (2003:63) and Bryant-Davis et al. (2012), positive thoughts are associated with high spirituality and appear to result in stronger coping styles, while the application of negative thoughts is associated with lower spirituality, resulting in weak coping styles.

Subsequently, this study aimed to explore how traffic officers experience the role of spirituality in coping within the South African work context and to provide a framework that can assist towards better understanding this phenomenon.

\section{Methodological approach}

Exploring the question 'how do traffic officers experience the role of spirituality in coping?' required a methodology of the heart with characteristics of truth (Denzin, Lincoln \& Giardina 2006:770). Therefore, the researcher considered the nature of the reality being studied (Ponterotto 2005:130), in selecting a qualitative study - specifically an interpretive approach - to explore participants' related lived experience in their specific context (Terre Blanche, Kelly \& Durrheim 2006:276). A non-probability purposive sample of 10 traffic officers was used (Durrheim \& Painter 2006:139), with a biographical composition consisting of one black, one white and eight mixed-race participants. Their gender distribution consisted of 6 males and four females of which 4 were between the ages of 26 and 35, 3 between the ages of 36 and 45, and 3 between the ages of 46 and 55 years.

The research was located within the South African traffic law enforcement environment, comprising a Law Enforcement Section within the particular Traffic Service Centre where they perform administrative duties, as well as the public roads according to the area of jurisdiction, where actual law enforcement takes place.

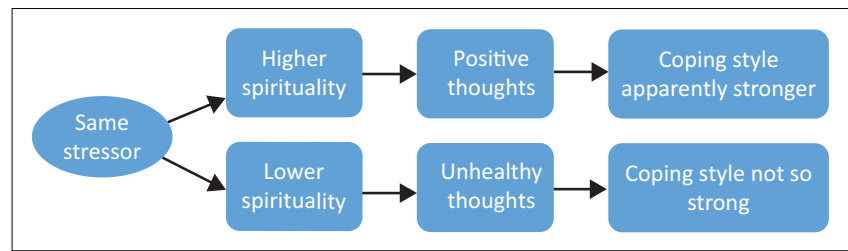

FIGURE 1: Theoretical relationship between spirituality and coping.
Data were collected with semi-structured, in-depth interviews. Interviews were primarily conducted away from the work environment to avoid interruptions, ensure privacy and create a relaxed environment (Kelly 2006a:298; Terre Blanche, Kelly \& Durrheim 2006:276). Permission was obtained from the participants to audio record the interviews and to make verbatim transcriptions (Koekemoer \& Mostert 2010:3; Wassenaar 2009:75). Conversing with traffic officers on two or more occasions further contributed towards ensuring that findings about their perceptions were correct representations of their views (Kelly 2006b:380).

Conventional content analysis was applied to analyse the data as it assisted with reducing textual data of subjective experiences into meaningful categories (McMillan \& Schumacher 2010:367; Muchinsky, Kriek \& Schreuder 2009:31) through inductive reasoning (Yin 2010:94).

\section{Findings}

The data analysis yielded various themes and subthemes that relate to spirituality, coping and the role of spirituality in the coping of traffic officers.

\section{Spirituality}

A foundation of spirituality or religion plays a fundamental role in the development and formation of the traffic officer's spirituality. Participants indicated that the influence of a higher power was important to their spirituality (Kinjerski \& Skrypnek 2008:319). In the challenging high-risk traffic environment (Mushwana 1998:134), traffic officers rely on this higher power for the protection of the self, family and different road users who are all at risk of accidents and dangerous incidents. Upbringing within spirituality or religion by parents and others seems to play a fundamental role in the formation of participants' foundation and subsequent views on spirituality. Participants further indicated that spirituality provided values and morals (Jacobs 2013:159), helping them to distinguish between right and wrong and to explore ethical aspects (Kourie 2009:168).

Participants suppose that spirituality informed the construction of their reality (Ponterotto 2005:130), and subsequently spirituality or religion dictates their lives through their actions and reflecting on the truth that they strive towards (Leedy \& Ormrod 2010:135). Furthermore, participants feel that spirituality gives purpose and meaning to life. Participants described that the guidance obtained from spirituality added meaning to work and life (McLeod 2003:142; Mohan \& Uys 2006:58), creating a feeling that work has purpose (Karakas 2010:20). This entails a desire to be of service and staying the course even in difficult times. Through spirituality, participants are able to be passionate about their work and view their career as a calling (Coetzee \& RoythorneJacobs 2012:220; Hall \& Chandler 2005:1; Karakas 2010:2). Spirituality, furthermore, seems to enable decision-making. Participants believe that they have the power to choose what they want to happen in their lives through mindful actions 
(Boehm \& Lyubomirsky 2009:1), by making conscious decisions informed by prayer and spiritual beliefs. They take responsibility for what manifests in their lives, thus acknowledging their free will (Bergh 2009:317).

Participants apply various strategies to connect to their higher power or spiritual source (Mohan \& Uys 2006:58). One such strategy is through involvement in church. One traffic officer thought it not necessary to go to church to experience this connection, thus viewing spirituality as independent from denomination (Karakas 2010:8). Traffic officers who value involvement in church use it as a coping mechanism, by drawing support and learning spiritual lessons from the social connections. Another strategy is through prayer. When connecting to their spiritual source (Kinjerski \& Skrypnek 2008:319), traffic officers use prayer to talk to God and ask for help in various situations (Mohan \& Uys 2006:58). Lastly, to sustain the connection with their higher power (Karakas 2010:8), the traffic officers use various spiritual resources, including listening to spiritual music, conversing with family and friends, or reading spiritual material.

Participants describe that spirituality manifests in their expression (Lombaard 2011:77) of values in their work and private lives. Individuals may be recognised by their actions or by the fruits of spirituality, which emerged primarily as calmness, positive attitudes, forgiveness, inner strength and awareness. Participants treasure the ability to become calm and exert self-control when faced with challenges. They must deal with the public's negative attitudes towards them (Pienaar 2007:63), thus the importance of dealing responsibly with emotions. A positive attitude is associated with spirituality, and the two cannot be separated (Rowe \& Allen 2003:64). Spirituality facilitates coping by inspiring positive attitudes, as participants are able to tap into their best, despite negative situations. Spirituality further fosters forgiveness, which apparently helps to overcome disappointment and moving forward (Schreuder \& Coetzee 2011:275). Forgiveness facilitates coping through helping traffic officers to voluntarily change how they feel about, and respond to, negative occurrences. Inner strength is important to participants as they view their higher power as a source of strength (Mohan \& Uys 2006:58), which makes it possible to withstand the demands of the job, and thus cope. Lastly, spirituality leads to an increased sense of awareness (Kinjerski \& Skrypnek 2004:32), including awareness of the self, of God and others. The awareness of negative consequences also emerged (Chopko 2007:89), involving the effects of one's actions or words on others.

\section{Coping}

Human context is vital to understanding coping (Moos 2002:67), thus background and upbringing emerged to include communities plagued by gangsterism, crime, violence, alcohol, drugs, poverty and peer pressure. Traffic officers revealed that childhood circumstances developed their coping abilities, because beliefs and spiritual values were instilled during childhood. Most participants appear to have been taught adaptive coping mechanisms at a young age.

The traffic work environment presents stressors (Mushwana 1998:134), the effects of which may manifest as aggression and frustration, adversely affecting relationships with others (Pienaar 2007:93). One such stressor is work conditions. Brutal incidents, crime and possibly being involved in accidents seem to pose a threat to work conditions. These may affect individuals emotionally and psychologically (Edwards 1992:245). Further, exhausting shift work or odd working hours may have a negative influence on physical well-being. A second stressor seems to be treatment from others. Traffic officers may face negative attitudes from road users (Pienaar 2007:63), poor treatment by colleagues and unfounded accusations. To cope participants may alter their perceptions around this treatment (Edwards 1992:243), alter distressed relationships between themselves and others, and regulate the emotional distress experienced (Boehmer, Luszczynska \& Schwarzer 2007:63). A further stressor appears to be inadequate coping mechanisms. Participants indicated that there are inadequate coping mechanisms and counselling services available at departmental level to assist in dealing with these stressors, and subsequently issues are just left without being attended to.

Personal coping mechanisms comprise positive attitudes, thankfulness and recreation, involving strategies employed to deal with stressors, as illustrated below. Participants also found it useful to surround themselves with positive people and to employ positive ways of thinking to assist them in coping with their work environment (Boehm \& Lyubomirsky 2009:1). Coping is also made possible by being thankful to God and people close to one in the midst of challenges. Traffic officers furthermore use physical activities and socialising to combat stress. The effects of stressors also manifest on physical levels (Edwards 1992:245), and recreational activities affect physical well-being and thus coping.

\section{The role of spirituality in the coping of traffic officers}

Participant spirituality entails an interpretation of spirituality, which may be taught during childhood or by conversing with others on scriptures. Interpreting the meaning of spirituality deepens their understanding of the positive fruits of spirituality, and positive thoughts contribute significantly to effective coping ability (Rowe \& Allen 2003:63). The ability to understand others and their views, and to respond to them in caring ways, is linked to the ability to cope effectively (Krishnakumar et al. 2015:21). The interpretation of spirituality facilitates better coping by enhancing social connections.

Life is understood through lived experiences (Welzen 2011:38), as reflected by traffic officers' implementation of spirituality. They apply what spirituality means to them within the context of work and life, which enables them to cope better. They treasure viewing their work in a spiritual 


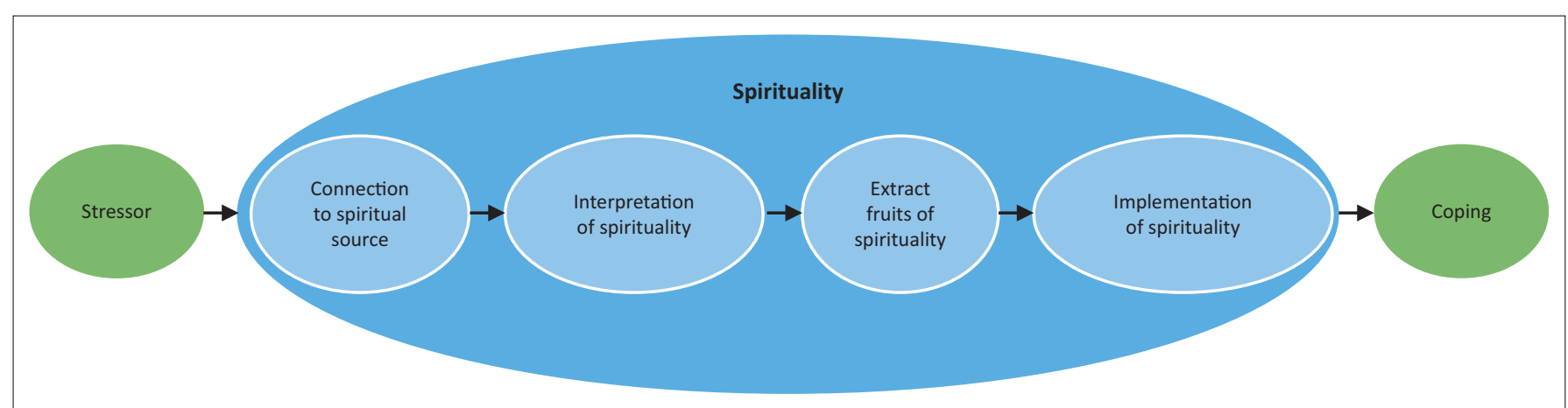

FIGURE 2: Framework towards understanding the role of spirituality in the coping of traffic officers.

way in order to persist and remain peaceful amidst challenges. It is within the context of their external work environment that one participant introduced the concept 'spirituality on the road' - a concept complementing the experiences of some other participants as well.

\section{Discussion}

Research findings revealed that traffic officers in the sample all utilised spirituality to various degrees and exhibited adaptive coping abilities when doing so. Traffic officers associated less spirituality or a lack thereof with weaker coping abilities. The following framework was derived (Figure 2) from the contributions of the participants and reflects their experiences regarding the role of spirituality in their coping as traffic officers:

- Stressors occur: It is sometimes expected of the traffic officers to still remain humane and unaffected, at the end of a shift, when something stressful has happened to them.

- Connection to spiritual source: In challenging times, individuals need to go to that emotional place where they can tap into their spiritual source or higher power.

- Interpretation of spirituality: The connection to the spiritual source enables the individual to become aware of what their spiritual source means to them, and how they are being served spiritually by this higher power.

- Extracting the fruits of spirituality: Individuals then take this spiritual meaning and extract what they need at the time, for example, inner strength, self-confidence or perseverance to deal with the given stressor.

- Implementation of spirituality: The spiritual resources received are then utilised in work and in life.

- Coping made possible: With the implementation of what spirituality means to the individual, or by applying the fruits of spirituality to the stressful situation, adaptive coping is made possible.

Future research may draw upon these findings and replicate the study with respondents from a wider variety of South African Traffic Services Centres. Research on the role of spirituality in the coping of traffic officers can also be expanded upon by exploring the influences of such factors as race, age and gender. Future research may also consider the latest relevance of spirituality in different religious contexts
(Jacobs 2013:144), as well as comparison with traffic officers who do not utilise spirituality at all in their opinion.

\section{Conclusion}

This article concludes that the utilisation of spirituality enables traffic officers to cope more effectively with the daily demands they are faced with. Spirituality in traffic officers is further informed by their foundation of spirituality or religion, purpose to work and life, the connection to their spiritual source and the fruits of spirituality. Their coping ability seems to be influenced by their upbringing and background, as well as by stressors encountered and coping mechanisms employed. The role of spirituality in the coping of traffic officers is ultimately described by their ability to interpret the meaning of spirituality and the implementation of spirituality, which facilitates coping.

\section{Acknowledgements Competing interests}

The authors declare that they have no financial or personal relationships that may have inappropriately influenced them in writing this article.

\section{Authors' contributions}

A.v.N. and R.J. were co-responsible for the experimental and project design. R.J. collected and analysed the data, with A.v.N. quality assuring the data collection and data analyses process. R.J. and A.v.N. co-wrote the manuscript.

\section{References}

Anderson, G.S., Litzenberger, R. \& Plecas, D., 2002, 'Physical evidence of police officer stress', Policing: An International Journal of Police Strategies \& Management 25(2), 399-420. http://dx.doi.org/10.1108/136395510210429437

Bergh, Z., 2009, 'Personality through self-experience', in Z. Bergh \& A. Theron (eds.), Psychology in the work context, pp. 315-330, Oxford University Press, Cape Town.

Boehm, J.K. \& Lyubomirsky, S., 2009, 'The promise of sustainable happiness', in Handbook of positive psychology, pp. 667-677, viewed 13 March 2014, from http://sonjalyubomirsky.com/wpcontent/themes/sonjalyubomirsky/papers/ BLinpressa.pdf

Boehmer, S., Luszczynska, A. \& Schwarzer, R., 2007, 'Coping and quality of life after tumor surgery: Personal and social resources promote different domains of quality of life', Anxiety, Stress, and Coping 20(1), 61-75. http://dx.doi. org/10.1080/10615800701195439

Bryant-Davis, T., Ellis, M.U., Burke-Maynard, E., Moon, N., Counts, P.A. \& Anderson, G. 2012, 'Religiosity, spirituality and trauma recovery in the lives of children and adolescents', Professional Psychology: Research and Practice 43(4), 306-314. http://dx.doi.org/10.1037/a0029282 
Cheng, T., Mauno, S. \& Lee, C., 2014, 'The buffering effect of coping strategies in the relationship between job insecurity and employee well-being' Economic and relationship between job insecurity and employee well-being', Economic and
IndustrialDemocracy35(1),71-94.http://dx.doi.org/10.1177/0143831X12463170

Chopko, B.A., 2007, 'The relationship between mindfulness and posttraumatic growth in law enforcement officers', PhD dissertation, University of Akron.

Coetzee, M. \& Roythorne-Jacobs, H., 2007, Career counselling and guidance in the workplace: A manual for career practitioners, Juta, Cape Town.

Coetzee, M. \& Roythorne-Jacobs, H., 2012, Career counselling and guidance in the workplace: A manual for career practitioners, 2 nd edn., Juta, Cape Town.

Coetzee, S.C., \& Viviers, A.M., 2007, 'An overview of research on positive psychology in South Africa', South African Journal of Psychology 37(3), 470-490. http://dx.doi. org/10.1177/008124630703700307

Collett, J.E., 2011, 'Of human bondage: Investigating the relationship between anorexia nervosa/bulimia, spirituality and the body-self alliance', PhD dissertation University of South Africa.

Criminal Procedure Act, No 51, 1977, Government Gazette Vol.555, No. 34583, Pretoria, viewed 8 October 2015, from http://www.google.com/url?sa=t\&rct= $j \& q=\&$ esrc $=s \&$ source $=w e b \& c d=2 \& v e d=0 C C I Q F j A B a h U K E w i z i 9 O Z s 7 P I A h U G V R$ QKHY6EDx4\&url=http\%3A\%2F\%2Fwww.lawsofsouthafrica.up.ac.za\%2Findex. php $\% 2$ Fbrowse $\% 2$ Fcriminal-law-and-criminal-procedure $\% 2$ Fcriminal-
procedure-act-51-of- $1977 \% 2$ Fact $\% 2$ F51-of-1977-criminal-procedure-act- 1 -sepprocedure-act-51-of-1977\%2Fact\%2F51-of-1977-criminal-procedure-act-1-sep-
1997-4-sep-1997pdf\%2Fdownload\&usg=AFQjCNGSEImRKN1fTXVEYcwj1c9mSc 1997-4-sep-1997pdf\%2Fdownload\&usg $=$
UWuw\&sig2=IONYct8VARJENPcxx6GY1Q

Denzin, N.K., Lincoln, Y.S. \& Giardina, M.D., 2006, 'Disciplining qualitative research 1', International Journal of Qualitative Studies in Education 19(6), 769-782. http:// dx.doi.org/10.1080/09518390600975990

Dewe, P., O'Driscoll, M. \& Cooper, C., 2010, 'Coping with work stress', Stress and Health 28(2), 175-176. http://dx.doi.org/10.1002/smi.1407

Durrheim, K. \& Painter, D., 2006, 'Collecting qualitative data: Sampling and measuring', in M. Terre Blance, K. Durrheim \& D. Painter (eds.), Research in practice: Applied methods for the social sciences, pp. 132-159, UCT Press, Cape Town.

Edwards, J.R., 1988, 'The determinants and consequences of coping with stress', in C.L. Cooper \& R. Payne (eds.), Causes, coping consequences of stress at work, pp. 233-266, Wiley, Chichester, viewed 19 October 2014, from http://public.kenanflagler.unc.edu/faculty/edwardsj/Edwards1988.pdf

Edwards, J.R., 1992, 'A cybernetic theory of stress, coping, and well-being', Academy of Management Review 17(2), 238-274, viewed 19 October 2014, from http:// public.kenan-flagler.unc.edu/faculty/edwardsj/Edwards1992.pdf

Gnanaprakash, C., 2013, 'Spirituality and resilience among post-graduate university students', Journal of Health Management 15(3), 383-396. http://dx.doi.org/ 10.1177/0972063413492046

Hall, D.T. \& Chandler, D.E., 2005, 'Psychological success: When the career is a calling', Journal of Organizational Behavior 26(2), 155-176. http://dx.doi.org/10.1002/ job.301

Jacobs, A.C., 2013, 'An evaluation of different kinds of spirituality', Journal for Christian Scholarship 49(3), 143-180, viewed 19 October 2014, from http://0-reference. sabinet.co.za.oasis.unisa.ac.za/document/EJC147235

Joubert, Y. \& Grobler, A., 2013, 'The value and extent of religious participation of members of the South African Police Service (SAPS)', Hervormde Teologiese Studies 69(1), 1-10. http://dx.doi.org/10.4102/hts.v69i1.1180

Karakas, F., 2010, 'Spirituality and performance in organizations: A literature review', Journal of Business Ethics 94(1), 89-106, viewed 6 April 2014, from http://oro. open.ac.uk/22966/2/Karakas(3).pdf

Kelly, K., 2006b, 'Calling it a day: Reaching conclusions in qualitative research', in M. Terre Blance, K. Durrheim \& D. Painter (eds.), Research in practice: Applied methods for the social sciences, pp. 370-387, UCT Press, Cape Town.

Kelly, K., 2006a, 'From encounter to text: Collecting data in qualitative research', in M. Terre Blance, K. Durrheim \& D. Painter (eds.), Research in practice: Applied methods for the social sciences, pp. 285-319, UCT Press, Cape Town.

Kinjerski, V. \& Skrypnek, B.J., 2008, 'Four paths to spirit at work: Journeys of personal meaning, fulfilment, well-being, and transcendence through work', The Career Development Quarterly 56(4), 319-329, viewed 15 March 2014, from http:// www.kaizensolutions.org/paths.pdf

Kinjerski, V.M. \& Skrypnek, B.J., 2004, 'Defining spirit at work: Finding common ground', Journal of Organizational Change Management 17(1), 26-42. http:// dx.doi.org/10.1108109534810410511288

Koekemoer, E. \& Mostert, K., 2010, 'An exploratory study of the interaction between work and personal life: Experiences of South African employees', SA Journal of Industrial Psychology 36(1), 1-15. http://dx.doi.org/10.4102/sajip.v36i1.801

Kourie, C., 2009, 'Spirituality and the University', Verbum Et Ecclesia 30(1), 145-173. http://dx.doi.org/10.4102/ve.v30i1.67

Krishnakumar, A., Narine, L., Soonthorndhada, A. \& Thianlai, K., 2015, 'Family stressors, home demands and responsibilities, coping resources, social connectedness, and Thai older adult health problems: Examining gender variations', Journal of Aging and Health 27, 257-283. http://dx.doi.org/10.1177/ 0898264314549658

Krok, D., 2008, 'The role of spirituality in coping: Examining the relationships between spiritual dimensions and coping styles', Mental Health, Religion and Culture 11(7) 643-653, viewed 6 April 2014, http://psycnet.apa.org/psycinfo/2008-14449-001

Leedy, P.D. \& Ormrod, J.E., 2010, Practical research: Planning and design, 11th edn., Prentice Hall, Upper Saddle River, NJ.
Lombaard, C., 2011, 'Biblical spirituality and human rights', Old Testament Essays 24(1), 74-93, viewed 10 September 2014, from http://0-reference.sabinet.co.zaoasis.unisa.ac.za/sa_epublications

Louw, G.J. \& Viviers, A., 2010, 'An evaluation of a psychosocial stress and coping model in the police work context', SA Journal of Industrial Psychology 36(1), 1-11. http:// dx.doi.org/10.4102/sajip.v35i1.442

Luthans, F., 2008, Organizational behaviour, 11th edn., McGraw Hill, Boston, MA

Luthans, F., 2011, Organizational behavior. An evidence-based approach, 12th edn., McGraw Hill, Boston, MA

McLeod, J., 2003, 'The humanistic paradigm', in R. Woolfe, W. Dryden \& S. Strawbridge (eds.), Handbook of counselling psychology, pp. 140-160, viewed 15 March 2014, from http://books.google.co.za/books?id=QwEYmVf6pcQC\&source=gbs_-book_ other_versions

McMillan, J.H. \& Schumacher, S., 2010, Research in education: Evidence based inquiry, 7th edn., Pearson., Boston, MA.

Mohan, D.L. \& Uys, K., 2006, 'Towards living with meaning and purpose: Spiritual perspectives of people at work', SA Journal of Industrial Psychology 32(1), 53-59, viewed 19 October 2014, from http://www.sajip.co.za/index.php/sajip/article/ viewFile/228/225

Moos, R.H., 2002, 'The mystery of human context and coping: An unravelling of clues', American Journal of Community Psychology 30(1), 67-89, viewed 10 October 2013, from http://www.ncbi.nlm.nih.gov/pubmed/11928778

Muchinsky, P.M., Kriek, H.J. \& Schreuder, A.M.G., 2009, Personnel psychology, 3rd edn., Oxford University Press, Cape Town.

Mushwana, S.E., 1998, 'The job involvement and job satisfaction of traffic officers and bus drivers', PhD dissertation, Rand Afrikaans University.

Naidoo, M., 2014, 'The potential of spiritual leadership in workplace spirituality', Koers - Bulletin for Christian Scholarship 79(2), 1-8. http://dx.doi.org/10.4102/ koersv79i22 124

National Road Traffic Act, No 93, 1996, viewed 08 October 2015, from http://www. acts.co.za/national-road-traffic-act-1996/

Pancheri, P., Martini, A., Tarsitani, L., Rosati, M.V., Biondi, M. \& Tomei, F., 2002, 'Assessment of subjective stress in the municipal police force of the city of Rome', Stress and Health 18(3), 127-132. http://dx.doi.org/10.1002/smi.936

Pienaar, J. \& Rothmann, S., 2003, 'Coping strategies in the South African police service', SA Journal of Industrial Psychology 29(4), 81-90, viewed 6 April 2014, from http://0-reference.sabinet.co.za.oasis.unisa.ac.za/webx/access/electronic journals/psyc/psyc_v29_n4_a9.pdf

Pienaar, J., Rothmann, S. \& Van De Vijver, F.J., 2007, 'Occupational stress, personality traits, coping strategies, and suicide ideation in the South African Police Service Criminal Justice and Behavior 34(2), 246-258. http://dx.doi.org/10.1177/009385 4806288708

Pienaar, J.F., 2007, 'Analysis of the training needs of traffic officers in the Potchefstroom district', PhD dissertation, North-West University.

Ponterotto, J.G., 2005, 'Qualitative research in counseling psychology: A primer on research paradigms and philosophy of science', Journal of Counseling Psychology 52(2), 126. http://dx.doi.org/10.1037/00220167522126

Rowe, M.M. \& Allen, R.G., 2003, 'Spirituality as a means of coping with chronic illness', American Journal of Health Studies 19(1), 62-66, viewed 10 October 2013, from http://www.biomedsearch.com/article/Spirituality-as-means-coping-with/ 115495864.html

Ryan, J., Rapley, M. \& Dziurawiec, S., 2014, 'The meaning of coping for psychiatric patients', Qualitative Health Research 24(8), 1068-1079. http://dx.doi.org/ 10.1177/1049732314541011

Schreuder, A.M.G. \& Coetzee, M., 2011, Careers: An organisational perspective, 4th edn., Juta, Cape Town

Smith, J. \& Charles, G., 2010, 'The relevance of spirituality in policing: A dual analysis', International Journal of Police Science \& Management 12(3), 320-338. http:// dx.doi.org/10.1350/ijps.2010.12.3.179

Terre Blanche, M., Kelly, K. \& Durrheim, K., 2006, 'Why qualitative research?', in M. Terre Blance, K. Durrheim \& D. Painter (eds.), Research in practice: Applied methods for the social sciences, pp. 271-284, UCT Press, Cape Town.

Theron, A., 2009, 'Motivation and emotion', in Z. Bergh \& A. Theron (eds.), Psychology in the work context, pp. 128-144, Oxford University Press, Cape Town.

Van Heerden, J.C., 1990, 'The effects of a stress innoculation programme on the reduction of the stress level of a multi-racial group of traffic officers', MSC dissertation, University of the Orange Free State.

Van Tonder, C.L. \& Ramdass, P., 2009, 'A spirited workplace: Employee perspectives on the meaning of workplace spirituality', SA Journal of Human Resource Management 7(1), 12. http://dx.doi.org/10.4102/sajhrm.v7i1.207

Waaijman, K., 2007, 'What is spirituality?', Acta Theologica 27(2), 1-18, viewed 19 October 2014, from http://www.ajol.info/index.php/actat/article/viewFile/52309/ 40934

Wassenaar, D., 2009, 'Ethical issues in social science research', in M. Terre Blance, K. Durrheim \& D. Painter (eds.), Research in practice: Applied methods for the social sciences, pp. 60-79, UCT Press, Cape Town.

Welzen, H., 2011, 'Contours of biblical spirituality as a discipline', Acta Theologica 31 37-60. http://dx.doi.org/10.4314/actat.v31i1S.4

Yin, R.K., 2010, Qualitative research from start to finish, Guilford Press, New York. 